\title{
Plasmodium translationally repressed gene products are essential for parasite development and malaria transmission
}

\author{
Jorge M Santos ${ }^{1 *}$, Pavitra N Rao ${ }^{2}$, Ana Guerreiro ${ }^{1}$, Leonor Pinho ${ }^{1}$, Céline K Carret ${ }^{1}$, Blandine MD Franke-Fayard ${ }^{3}$, \\ Thomas J Templeton², Chris J Janse ${ }^{3}$, Gunnar R Mair ${ }^{1}$
}

From Challenges in malaria research

Basel, Switzerland. 10-12 October 2012

\section{Background}

The sexual and ookinete development of Plasmodium relies on the translation of mRNAs supplied maternally in the macro-gametocyte as translationally repressed transcripts [1]. Translational repression depends on the interaction of mRNAs and RNA binding proteins such as DOZI and CITH; their absence results in mRNA destabilisation and developmental arrest of the parasite in the mosquito midgut [2]. Among the repressed mRNAs $\sim 40$ encode for potential surface molecules or adhesins. While some are well-characterised (e.g. P25 and P28), most are putative with no known function or homology. pb25/pb28 gene disruption severely impairs parasite development [3] while the presence of anti-P25 and antiP28 antibodies in a blood meal reduces mosquito infection $[4,5]$. A P25-based transmission blocking vaccine (TBV) has reached human phase 1 clinical trials but results have not been fully satisfactory [6]. For this reason, novel antigens are being pursued as targets of malaria TBVs.

\section{Materials and methods}

RIP-Chip and RT-PCR of immunoprecipitated DOZI and CITH mRNPs from the rodent malaria parasite P. berghei were used to identify molecules with clear surface targeting signals that are associated with P body-like mRNPs. Targeted gene deletion and GFP-tagging was used to identify the function, sub-cellular localisation and expression patterns of these proteins. To study the development of knock-out parasite lines, Anopheles stephensi mosquitoes were allowed to feed on infected mice and infection was

${ }^{1}$ Unidade de Parasitologia Molecular, Instituto de Medicina Molecular, Av. Prof. Egas Moniz, 1649-028 Lisbon, Portugal

Full list of author information is available at the end of the article quantified at the oocyst and sporozoite stages. In silico analysis identified highly immunogenic peptides in each protein; they were concatenated as codon-optimised, chimerical $\mathrm{His}_{6}$-tagged fusion proteins for heterologous expression to be used in transmission blocking assays.

\section{Results}

22 mRNAs encoding for surface proteins were shown to be associated with both DOZI- and CITH-defined mRNPs. These include $p b 25, p b 28$, the entire $p b-f a m-5$ family, as well as 12 uncharacterised gene products with orthologs in P. falciparum and P. vivax; the latter were targeted for gene deletion. Several of the knock-out mutants show a clear impairment in mosquito stage development, either at the oocyst or sporozoite levels. Some of these completely fail to transmit to naïve mice. Full length and concatenated versions (superantigens) of these proteins were expressed in Escherichia coli BL21. Superantigen expression was achieved more easily and in higher yields than full-length proteins.

\section{Conclusions}

Here we identify novel $P$. berghei translationally repressed mRNAs that encode for mosquito stage surface proteins and are important for parasite development within its vector. Parasites lacking some of these proteins fail to transmit to naïve hosts, and are therefore attractive targets for novel transmission blocking vaccines. Heterologous expression of Plasmodium protein is frequently a challenging task due to their disordered nature and the $\mathrm{A} / \mathrm{T}$ richness of the genome. We used codon optimisation to compensate for $\mathrm{A} / \mathrm{T}$ rich genes and developed a superantigen strategy to combine the most immunogenic regions of several proteins while avoiding their hydrophobic domains. 
The results show that our superantigens are more easily expressed in bacteria, and in higher amounts. This will enable us to use them in transmission blocking assays, targeting more than one parasite surface protein at the same time.

\section{Author details}

${ }^{1}$ Unidade de Parasitologia Molecular, Instituto de Medicina Molecular, Av. Prof. Egas Moniz, 1649-028 Lisbon, Portugal. ²Department of Microbiology and Immunology, Weill Cornell Medical College, New York 10021, USA.

${ }^{3}$ Leiden Malaria Research Group, Department of Parasitology, Leiden

University Medical Center, 2333 ZA Leiden, Netherlands.

Published: 15 October 2012

\section{References}

1. Mair GR, Braks JAM, Garver LS, Wiegant JCAG, Hall N, Dirks RW, Khan SM, Dimopoulos G, Janse CJ, Waters AP: Regulation of sexual development of Plasmodium by translational repression. Science 2006, 313:667-669.

2. Mair GR, Lasonder E, Garver LS, Franke-Fayard BMD, Carret CK, Wiegant JCAG, Dirks RW, Dimopoulos G, Janse CJ, Waters AP: Universal features of post-transcriptional gene regulation are critical for Plasmodium zygote development. PLoS Pathog 6:e1000767.

3. Tomas AM, Margos G, Dimopoulos G, van Lin LH, de Koning-Ward TF, Sinha R, Lupetti P, Beetsma AL, Rodriguez MC, Karras M, Hager A, Mendoza J, Butcher GA, Kafatos F, Janse CJ, Waters AP, Sinden RE: P25 and P28 proteins of the malaria ookinete surface have multiple and partially redundant functions. EMBO J 2001, 20:3975-3983.

4. Hisaeda H, Stowers AW, Tsuboi T, Collins WE, Sattabongkot JS, Suwanabun N, Torii M, Kaslow DC: Antibodies to malaria vaccine candidates Pvs25 and Pvs28 completely block the ability of Plasmodium vivax to infect mosquitoes. Infect Immun 2000, 68:6618-6623.

5. Gozar MMG, Price VL, Kaslow DC: Saccharomyces cerevisiae-secreted fusion proteins Pfs 25 and Pfs 28 elicit potent Plasmodium falciparum transmission-blocking antibodies in mice. Infect Immun 1998, 66:59-64.

6. Carter R: Transmission blocking malaria vaccines. Vaccine 2001, 19:2309-2314.

doi:10.1186/1475-2875-11-S1-P85

Cite this article as: Santos et al: Plasmodium translationally repressed gene products are essential for parasite development and malaria transmission. Malaria Journal 2012 11(Suppl 1):P85.

\section{Submit your next manuscript to BioMed Central and take full advantage of:}

- Convenient online submission

- Thorough peer review

- No space constraints or color figure charges

- Immediate publication on acceptance

- Inclusion in PubMed, CAS, Scopus and Google Scholar

- Research which is freely available for redistribution

Submit your manuscript at www.biomedcentral.com/submit
Biomed Central 